\title{
Around the Idea of Compromise. The activity of the Polish Peasant Party "New Liberation" on the forum of the State National Council and Parliament (with a particular emphasis on education) ${ }^{1}$
}

\begin{abstract}
PSL „New Liberation” tried to win the villages. It highlighted its association with one of the major pre-war left-wing peasant parties: PSL „Liberation”. Before the war it had gathered many village teachers, focusing its attention on the modernization and development of education. The „New Liberation” declared great concern for the state (including education); it emphasized the importance of religion; it ensured that in the new political realities, an educated peasant „should not be a laughing stock, as it used to be previously, but a citizen enjoying full rights". The party emphasized the role of peasant educational organizations: „the tremendous importance of this work, which seeks to abolish the eternal harm suffered

1 This text was created as part of a project dedicated to PSL "New Liberation", PSL "Left" and "reborn" PSL. The project was funded by the National Science Center (Niniejszy tekst powstał w ramach projektu pt. Dywersja w ruchu ludowym czy próby pójścia na kompromis $z$ komunistami. Miejsce na scenie politycznej i losy PSL "Nowe Wyzwolenie", PSL "Lewica" oraz "odrodzonego" PSL w latach 1946-1949 (1950) sfinansowanego ze środków Narodowego Centrum Nauki).

Some of the issues raised in this text are discussed particularly in the article: T. Skrzyński, Reprezentacja PSL „Nowe Wyzwolenie”, PSL „Lewica” i „odrodzonego” PSL w Krajowej Radzie Narodowej i Sejmie Ustawodawczym, „Rocznik Historyczny Muzeum Historii Polskiego Ruchu Ludowego" (2016) nr 32 and in the text: Wokót idei kompromisu written in February 2017 for post-conference materials „Kształtowanie społeczeństwa wieloświatopoglądowego” (28-29 IX 2016).
\end{abstract}


by the neglected peasant child.” „New Liberation” persuaded the peasants that they should abandon their rivalry with the Communists and Socialists. The aim was to cooperate on equal terms. But, the idea of „New Liberation” to partially represent the interests of the village in the parliament was unreal. The „liberators” failed to notice the insincerity in PPR policy. The aim of this article is to recall the main activities of the Polish Peasant Party "New Liberation" on the forum of the State National Council and Parliament.

\section{Keywords}

Polish Peasant Party „New Liberation”. Stanislaw Bańczyk, State National Council, Ignacy Klimaszewski, Legislative Sejm, Tadeusz Rek.

The Polish literature concerning this subject is quite extensive as far as the views of supporters and opponents of the system built in Poland since 1944 is concerned. It is worthwhile, however, to show the views of these few politicians who, in 1946 and 1947, had different opinions. They believed that political compromise was possible at the time. Especially important for them was to present their views in the parliament. The education was of particular importance for the peasant party. Due to this fact, in this article special attention will be paid to this issue.

In autumn of 1945 there were three peasant parties in Poland. All three had deputies in the State National Council (KRN), a substitute for parliament. ${ }^{2}$

Definitely the most important party was the Polish Peasant Party (PSL). ${ }^{3}$ It was headed by the recent Prime Minister of the Polish Republic Stanislaw Mikolajczyk. PSL was driven by the ideas of agrarianism. It headed to democracy and aspired to obtain the most important position in the state for peasants treated as a "major source of cultural and national wealth." (approx. 65\% of the country population). ${ }^{5}$

2 i.a. H. Cimek, Elity ruchu ludowego w Polsce w latach 1944-1949, Rzeszów 2016, Wydawnictwo Uniwersytetu Rzeszowskiego, pp. 156, 203, 210.

3 The most important national study on PSL is still the book of Romuald Turkowski, Polskie Stronnictwo Ludowe w obronie demokracji 1945-1949, Warszawa 1992, Wydawnictwo Sejmowe.

${ }^{4}$ J. Krasuski, Ruch ludowy wobec szkolnictwa i oświaty wiejskiej w Polsce w latach 19391949, Kielce 1993, Wyższa Szkoła Pedagogiczna, p. 151.

${ }^{5}$ More on agrarianism in Poland i. a.: Wieś i ruch ludowy w Polsce i Europie. t. 2: Idee, organizacje, środowisko, eds. F. Kampka, S. Stępka, Warszawa 2012, Muzeum Historii Polskiego 
Stanislaw Bańczyk's supporters tried to reconcile agrarianism and the regime which was built by the communists. The important thing was inter alia the necessity of peasant upward social advancement, proclaimed by the Polish Workers' Party (PPR). Its essential element was the real, universal access to education for peasant children at all its levels. ${ }^{6}$ The deputies of the Bańczyk Party (8-10 altogether) were active in the Association of Rural Youth of the Republic of Poland „Wici” (they were represented in its leadership).

This organization, which was a part of the peasant movement, was very active in the field of education in the country. The Bańczyk's party did not, however, have a real impact on the state policy towards peasants. The party had to, i.a. powerlessly, watch the badly paid teachers' mass departure to cities ${ }^{7}$. In the autumn of 1945, due to these losses, lots of country children were deprived of opportunities to gain elementary education. In this situation, the leadership of the Bańczyk Party decided to unite with the PSL (November 1945). ${ }^{8}$

The party which had the least influence amongst Polish peasants in autumn 1945 was the, so-called. „Lublin” Peasant Party (SL) ${ }^{9}$. It was fully controlled by the communists. It had no influence in the regional or local structures of other organizations belonging to the peasants' movement. The examples were

Ruchu Ludowego i Wydział Nauk Społecznych SGGW, Ludowe Towarzystwo Naukowo-Kulturalne; Historia i tradycje ruchu ludowego, T. 1, Ideologia, polityka i jej kreatorzy, red. J. Gmitruk, A. Indraszczyk, Warszawa - Kielce 2016, Muzeum Historii Polskiego Ruchu Ludowego, Ludowe Towarzystwo Naukowo-Kulturalne, Wszechnica Świętokrzyska. There is a selection of further literature on the subject. The latest work concerning the members of peasant party' views on education is text: $\mathrm{M}$. Januszewska-Warych, W poszukiwaniu nowoczesnej demokratycznej i narodowej wizji reformy szkolnictwa. Ogólnopolski Zjazd Oświatowy (Łódź 18-22 czerwca 1945 roku), Kraków 2015, Impuls.

${ }^{6}$ As for the recent publications concerning education between 1945-1947 see D. Gałaczewska - Hilczuk, J. W. Wołoszyn, Od przedszkolaka do studenta. Kryteria selekcji społecznej i politycznej w edukacji lat 1947-1956, Lublin 2012, IPN; L. Szuba, Polityka oświatowa państwa polskiego w latach 1944-1956, Lublin 2002, Towarzystwo Naukowe KUL. As for the older works concerning PPR policy on education see Cz. Lewandowski, Kierunki tak zwanej ofensywy ideologicznej w polskiej oświacie, nauce i szkołach wyższych w latach 1944-1948, Wrocław 1993, Wydawnictwo Uniwersytetu Wrocławskiego.

7 i.a. S. Mauersberg, Reforma szkolnictwa w Polsce w latach 1944-1948, Wrocław 1974, Polska Akademia Nauk, p. 60.

${ }^{8}$ H. Cimek, Elity Polskiego Stronnictwa Ludowego (sierpień 1945 r. - październik 1947 r.), "Zeszyty Wiejskie" 21 (2015), p. 104.

${ }^{9}$ For the most important work on this topic is still the book, published at the end of PRL by A. Mieczkowski, Geneza i działalność polityczna Stronnictwa Ludowego 1944-1949, Lublin 1987, Uniwersytet Marii Curie-Skłodowskiej. 
national educational organizations consisting of many thousands of members: the Society of Dormitories and Scholarships of the Republic of Poland (TBS), the Peasant Society of Children Friends (ChTPD) or the more elitist Society of People's Universities (TUL).

Since the spring of 1946, PPR had intensified repression against the Polish Peasant Party. Some PSL top officials were certain that PSL would lose in confrontation with the growing terror. They tried to persuade the leadership of PSL to change the present PSL policy towards PPR.

In June 1946 some of the critics of Mikolajczyk's policy started publishing their own magazine. At the head of this group stood nearly all the former top leadership of the Bańczyk party. This group was led by a lawyer Tadeusz Rek and a teacher Bronisław Drzewiecki. It had some influence in the country, including the structures of „Wici” and other popular educational organizations in the country. ${ }^{10}$

In this situation PSL leadership tried to divide the supporters of the magazine. It expelled the most important supporters of the magazine from PSL. In response, in June, they started and took the lead of a new party: the Polish Peasant Party „New Liberation” („New Liberation”). The leaders were: Rek and deputies: Drzewiecki, Edward Bertold and the then deputy minister Kazimierz Iwanowski. In July another MP, the teacher Michał Rękas was joined to them." ${ }^{11}$ Within a few months, many of Bańczyk's recent supporters joined the „New Liberation”. Among them were Ludwik Denisiuk, Felix Pisula and Jan Lorek-Sek. ${ }^{12}$

The party established its structures, or was trying to do so, in at least $40 \%$ of counties in Poland. It gained influence in all layers of the society. It organized

${ }^{10}$ For the most widely read publications about "Liberators" at the level of voivodeships: J. Romanek, Powstanie i działalność Polskiego Stronnictwa Ludowego „Nowe Wyzwolenie” $w$ województwie lubelskim, „Rocznik Historyczny Muzeum Historii Polskiego Ruchu Ludowego” 27 (2011), pp. 129-141; T. Skrzyński, Z dziejów Polskiego Stronnictwa Ludowego „Nowe Wyzwolenie” w województwie krakowskim w 1946 i 1947 roku, „Biuletyn Biblioteki Jagiellońskiej” 54 (2004), pp. 193-207; M. Szpytma, Próby dezintegracji ruchu ludowego w Polsce południowej na przykładzie Małopolskiej Grupy „Jedność Ludowa” (1946-1947), in: Represje wobec wsi i ruchu ludowego 1944-1956. Materiały z konferencji naukowej, 1, eds. J. Gmitruk, Z. Nawrocki, Warszawa 2003, Muzeum Historii Polskiego Ruchu Ludowego, IPN, pp. 115-132. It is worth mentioning that one of the places where „liberators” were active in 1946 was Niegowić. Coincidentally, less than two years later, Karol Wojtyla began his pastoral ministry there.

${ }^{11}$ H. Cimek, Elity Polskiego..., p. 104.

12 T. Skrzyński, Miejsce na scenie politycznej i losy PSL „Nowe Wyzwolenie”, PSL „Lewica” oraz „odrodzonego" PSL w latach 1946-1949 (1950), Warszawa 2015, Muzeum Historii Polskiego Ruchu Ludowego, p. 92. 
i.a. a few student groups. ${ }^{13}$ By January 1947, thousands of people, not previously associated with the Bańczyk party, joined it. One of them was another MP, educational activist, school inspector Ignacy Klimaszewski. ${ }^{14}$ "New Liberation” tried to win the country. It highlighted its association with one of the major pre-war left-wing peasant parties: PSL „Liberation”. ${ }^{15}$ Before the war it had attracted many peasant teachers and paid attention to the modernization and development of education in the country.

It was not surprising that in „New Liberation” newspapers there were constant references to carefully selected views of pre-war left and center peasant activists ${ }^{16}$. Several pre-war PSL MPs from „Wyzwolenie” (i.a. Kazimierz Stępień - Łódzkie Voivodeship) were also successfully acquired. ${ }^{17}$

The „New Liberation” declared great concern for the state (including education); emphasized the importance of religion and ensured that in the new political realities, an educated peasant ,should not be a laughing stock, as it used to be previously, but a citizen enjoying full rights". ${ }^{18}$

The party emphasized the role of peasant educational organizations ,the tremendous importance of this work, which seeks to abolish the eternal harm

${ }^{13}$ More on this subject: T. Skrzyński, Struktury regionalne i lokalne PSL "Nowe Wyzwolenie", in: Historia i tradycje ruchu ludowego, t. 2, eds. J. Gmitruk, A. Indraszczyk, Warszawa-Kielce 2016, Muzeum Historii Polskiego Ruchu Ludowego, Wszechnica Świętokrzyska w Kielcach, Ludowe Towarzystwo Naukowo-Kulturalne, pp. 445-461.

${ }^{14}$ H. Cimek, Elity..., pp. 113, 153.

15 Do członków i sympatyków Polskiego Stronnictwa Ludowego, „Nowe Wyzwolenie” 1 (1946), p. 1. More about PSL "New Liberation" point of view in: T. Skrzyński, Kompromis czy kapitulacja. Poglądy PSL „Nowe Wyzwolenie”, PSL „Lewica” i „odrodzonego” PSL na ustrój, rolę i zakres państwa w latach 1946-1949, in: Partie i ruchy chłopskie i ludowe w Europie wobec problemów współczesności. Państwo - forma, rola i zadania, eds. J. Gmitruk, A. Indraszczyk, S. Stępka, Warszawa 2014, Muzeum Historii Polskiego Ruchu Ludowego i Wydział Nauk Społecznych SGGW, s. 33-55; K. Dziubka, Władza, administracja i samorząd w koncepcjach polskiego ruchu ludowego 1944-1949, Wrocław 1992, Wydawnictwo Uniwersytetu Wrocławskiego, pp. 36-37, 41, 50, 62, 72-73, 81; A. Wojtas, Problematyka agrarna w polskiej myśli politycznej 1918-1948, Warszawa 1983, Ludowa Spółdzielnia Wydawnicza, p. 335.

16 i.a. Myśli Józefa Grudzińskiego, „Nowe Wyzwolenie” 5 (1947), p. 5.

17 Archiwum Instytutu Pamięci Narodowej w Warszawie (IPN), BU 0/1355/141 Special report of the Provincial Public Security Office Łódź to the Ministry of Public Security z 9 XI 1946, p. 198.

18 „Sprawozdanie Stenograficzne z Posiedzeń Krajowej Rady Narodowej”, 11 (1946), column 89. 
suffered by the neglected peasant child." ${ }^{19}$ The Warsaw University of Agricultural Sciences (SGGW) was also supported. ${ }^{20}$

From the communists' point of view „The New Liberation” was supposed to "grasp the organizations of all those sincere members of PSL who disagree with the policy represented by Mikolajczyk." ${ }^{21}$ Communists' and socialists' support for „New Liberation” ${ }^{22}$ however, was badly perceived by peasants and resulted in low credibility of this party, i. a. among the members of the organizations involved in rural education (eg „Wici”, TUL, ChTPD and TBS). The activists of these organizations belonging to the „New Liberation” were few. ${ }^{23}$ This was also the result of the opposition to the PSL. For the Mikolajczyk party, subjected to repressions, education and rural educational organizations were ,an important and often only possible form of influence on peasant masses." ${ }^{24}$

"New Liberation" persuaded the peasants that they should abandon their rivalry with the Communists and Socialists. The aim was to cooperate on equal terms. It was necessary to create, in the country, „a favorable political climate, a climate that allowed bringing domestic relationships back to normal as fast as possible, together with moral and material reconstruction. ${ }^{25}$

According to the „New Liberation," the opposition in parliament was to point out to the government their errors as well as the way to of correcting them. It was supposed to help the Communists in government. ${ }^{26}$ According to „New Liberation”, PSL MPs did not have such pro-state intentions. A tool for carrying out of the strategy described by the „New Liberation” in parliament was

19 Chłopskie Towarzystwo Przyjaciół Dzieci, „Nowe Wyzwolenie” 2 (1946), p. 6. Kursy TUL Przesunięcie terminu zgłoszenia kandydatów i rozpoczęcia kursów, „Nowe Wyzwolenie” 26 (1946), p. 16.

20 i.a. Szkoła Główna Gospodarstwa Wiejskiego w Łodzi, „Nowe Wyzwolenie” 3 (1946), p. 12.

${ }^{21}$ IPN BU 0/1355/141 Special report of the Provincial Public Security Office Łódź to the Ministry of Public Security 9 XI 1946, p. 197.

22 T. Skrzyński, Polskie Stronnictwo Ludowe „Nowe Wyzwolenie” w świetle sprawozdań Komitetów Wojewódzkich PPR i Wojewódzkich Komitetów PPS (czerwiec 1946 - styczeń 1947), „Przegląd Nauk Historycznych” 13 (2014) 1, pp. 167-185.

${ }^{23}$ i. a. Protokół posiedzenia NKW PSL z 25 VI 1946, in: Polskie Stronnictwo Ludowe w latach 1945-1946. Dokumenty do dziejów niezależnego ruchu ludowego w Polsce, prepared for printing W. Bartoszewski, Warszawa 1981, pp. 125-126.

${ }^{24}$ J. Krasuski, Ruch..., p. 151.

25 F. Sadurski, Istotny sens wyborów, „Nowe Wyzwolenie” 25 (1946), p. 1.

${ }^{26}$ B. Kubski, Negacja i opozycja, „Nowe Wyzwolenie” 2 (1946), pp. 4-5. 
its parliamentary club. ${ }^{27}$ The conditions for the implementation of the strategy described by the „New Liberation” were, however, difficult. It was no coincidence that the first speech of the Party representative - in the whole KRN (in September 1946), took place after the speeches of party representatives supporting the PPR policy. Iwanowski was preceded by the following deputies: a representative of the frail Labor Party, Democratic Party which was experiencing internal crisis and the marginal Jewish Socialist Party. ${ }^{28}$ After the speech of the member of parliament from the "New Liberation” the only one was the representative of the opposition from PSL. ${ }^{29}$ There is also similarity in the context of the most important speech of „New Liberation” at the plenary sessions of the KRN made by Rek. ${ }^{30}$ The PPR then gave the Party a voice after the Democratic Party and before the Labor Party and a representative of the marginal on Polish political scene left - wing „Poalej Syjon”. ${ }^{31}$

In the discussion on the Budget of the Ministry of Agriculture and Agrarian Reform Kazimierz Iwanowski appealed for the support for individual farms in the Recovered Territories (i.e. former eastern provinces of Germany). In particular, he was thinking of those which represented "a sufficiently high level" of agriculture. He appealed for funds to allow agriculture to develop. In accordance to the ideas of agrarianism, he emphasized: "The problem of agriculture is approached from two points of view: the first point - they are feeding, the second - they are defending. He considered agricultural production as ,the foundation of the State on which reasonable development of the industry can be laid". He emphasized that, while rebuilding Warsaw, an important place among other public buildings should have „the center of peasant culture, the state house of peasants." ${ }^{32}$

The party criticized Poland's plan of economic recovery and its guidelines. Edward Bertold started from the advantages of the project. Then he clearly pointed out the most important weaknesses of the plan and its guidelines. These

${ }^{27}$ Sejm Ustawodawczy Rzeczypospolitej Polskiej (1947-1952), ed. M. Rybicki, Wrocław Warszawa 1977, Ossolineum, pp. 160-161, 163.

${ }^{28}$ In the KRN there were three members of the Jewish party.

29 Sprawozdanie stenograficzne..., columns 67-93.

${ }^{30}$ Despite the objections of the PSL deputies, in September's plenary session the KRN agreed that he might be a deputy (Sprawozdanie stenograficzne...., column 25).

31 Sprawozdanie stenograficzne..., columns 312-337.

32 Sprawozdanie stenograficzne..., columns 86-89 (4 quotation). Realised after years the idea of constructing the Peasant's Home has not yet come to a monographic description. 
represented significant support for urban development at the expense of the country, and lack of support for the owners of individual farms. He called for substantial increase in government support for the generally meant agriculture. Eventually, however, he supported the government's proposal. ${ }^{33}$

Rek's appeals for the complete equality of the country and the city in political, economic and cultural terms were fruitless. ${ }^{34}$ Not surprisingly was the result of substantial amendments of the "New Liberation" to the electoral law.

Only four MPs from the „New Liberation” supported them. ${ }^{35}$ The criticism of PSL by the „New Liberation” was not helpful. Finally, during the vote „New Liberation" supported the electoral law in the form proposed by the PPR. ${ }^{36}$ Those MPs who later joined „New Liberation” ranks, voted against or were absent. $^{37}$

At the same time, during the same plenary session of the KRN, in the face of acute disputes, the "New Liberation” Club pledged to "maintain the tone and contents" of its members' speeches at such a level that they would not result in „justified sanctions." ${ }^{38}$ This commitment was made by all parliamentary clubs. Its significance for the „New Liberation” was, however, greater. The political position of the „liberators" was weaker than the other Polish political parties. ${ }^{39}$ This commitment turned out to be one of the signs of the „visible and planned pursuit" of the PPR „to gag deputies from other parties [...] and to restrict the deputies' freedom of speech." ${ }^{30}$

${ }^{33}$ O planie odbudowy. Przemówienie posła E. Bertolda, „Nowe Wyzwolenie” 17 (1946), pp. 5-6.

${ }^{34}$ Ordynacja wyborcza. Przemówienie posła T. Reka, „Nowe Wyzwolenie” 17 (1946), pp. 7-8.

35 Sprawozdanie stenograficzne..., columns 357-358.

${ }^{36}$ J. Stępień, Spory wokół projektów ordynacji wyborczej do Sejmu Ustawodawczego w 1946 r., „Czasopismo Prawno-Historyczne” 1 (1997), pp. 155, 158.

37 Sprawozdanie Stenograficzne..., columns 521-527.

38 Sprawozdanie stenograficzne..., column 94.

${ }^{39}$ For the most comprehensive publication regarding the balance of system of political forces in the forties see: J. Wrona, System partyjny w Polsce 1944-1950. Miejsce - funkcje relacje partii politycznych $w$ warunkach budowy i utrwalania systemu totalitarnego, Lublin 1997, Uniwersytet Marii Curie-Skłodowskiej; B. Barnaszewski, Polityka PPR wobec zalegalizowanych partii i stronnictw, Warszawa 1996, Semper.

40 A quotation from the speech of PSL deputy Zygmunt Załęski (Sprawozdanie stenograficzne..., column 262). 
It is not surprising, therefore, that the "New Liberation” MPs did not speak in discussions on the reports of the KRN committees such as education committee. ${ }^{41}$ At that very moment the temperature of the political dispute in the chamber was such that "constructive criticism” could not bring the Party any benefits. It was thought that the discussion would only be a pretext for attacking PSL by PPR and its allies.

It should be emphasized, however, that at least two or three members of the parliament were involved in the discussions of the committees' reports, often only one of the ruling coalition and another of PSL. Another thing is that, the future deputy of „New Liberation”, Klimaszewski took part in the discussion on behalf of the education committee. He could not appear in the KRN as a member of the „New Liberation” because between the date of its transfer to Rek and Drzewiecki's party and parliamentary elections there was not a single plenary meeting.

During the September plenary session of the KRN, „New Liberation” deputies did not take part in discussions on another occasion. The discussion on the acceptance by the KRN of an international convention on the establishment of the United Nations Educational, Scientific and Cultural Organization (UNESCO) was not substantial. It was only a pretext for an acute attack on the PSL. The representative of the „Lublin” SL justified that one of the main ideas of UNESCO is „creating a man of a new Europe”. He found it necessary to obtain acceptance, by all those present in the chamber of this "role model" of a new man presented by PPR. ${ }^{42}$ It was against the ideas of agrarianism supported by „New Liberation”.

None of the „New Liberation” MPs spoke in discussion about the imposed consolidation of cooperative banks. Supporting the authorities was not in line with the expectations of the peasants. On the other hand, supporting the PSL deputy Pawel Chadaj was politically dangerous. ${ }^{43}$ It was best to remain silent.

Similarly the limited were the opportunities that the "liberators" had to present their political line in almost all permanent committees within KRN. In theory, the greatest opportunities were regarding the committee dealing with education, whose chairman was Klimaszewski. However, for some time there was an obstacle resulted of the PPR plans concerning the Minister of Education

${ }^{41}$ Sprawozdanie stenograficzne..., columns 384-475.

42 Sprawozdanie stenograficzne..., columns 361-370.

${ }^{43}$ Sprawozdanie stenograficzne..., columns 391-392. How the deputies of "New Liberation" voted is impossible to establish. 
of PSL Czesław Wycech. Władysław Gomułka ${ }^{44}$ wanted to attract him for the coalition. ${ }^{45}$ In the forum of the educational committee Klimaszewski spoke about the project of the New School Act. In December 1946 he wrote very positively about it in the „New Liberation” newspapers.

He definitely was less optimistic about the situation of schools in the country. The lack of teachers was understood as the most important problem of Polish education system in the country. The precondition for the teachers was, he considered, a substantial increase in their earnings. He stressed: „The new agricultural reform is most of all needed for the country." ${ }^{36}$ Iwanowski, however, drew attention to the most important document of the Party, that although the government's current educational policy „raises the best hope for the future, the peasants must keep an eye so that the rural sector would not be disadvantaged in comparison with the city." He also stressed the necessity of liquidation of the partial funding of teachers by the village, which was very common in the country. ${ }^{47}$

At the same time, in "New Liberation” newspapers, they fruitlessly emphasized the necessity of developing agricultural education so that ,it became common for a future new farmer to complete a commune or district agricultural school." ${ }^{38}$

In the autumn of 1946, the ideas of the "New Liberation" that it would act as a "constructive opposition" between the ruling coalition and PSL, proved to be unrealistic. In the election, the leadership of „New Liberation” decided to support formally the block of parties gathered around the Communists.

At the end of 1946 and at the beginning of 1947 it was most important for PPR to destroy PSL structures by terror. The majority of hundreds of PSL activists in schools, TULs, ChTPDs, or TBS ${ }^{49}$ acquired in those circumstances did not support sincerely the „New Liberation”. The presence of individual „liberators” at various levels in boards of these educational organizations was probably

${ }^{44}$ As for the recently issued publication about the leader of PPR see: A. Prażmowska, Władysław Gomułka, Londyn 2016, Wydawnictwo RM, pp. 7-281.

${ }^{45}$ He belonged to the leadership of the leading PSL supporters of the compromise with Communists. About his furtherfate see: R. Turkowski, Powstanie i działalność Polskiego Stronnictwa Ludowego „Lewica” (1946-1947), in: Studia i szkice z dziejów najnowszych, ed. M. Tanty, Warszawa 1987, Centralny Ośrodek Metodyczny Studiów Nauk Politycznych.

\footnotetext{
46 I. Klimaszewski, O reformie szkolnej, „Nowe Wyzwolenie” 27 (1946), p. 12.

47 K. Iwanowski, Czego żąda wieś, „Nowe Wyzwolenie” 25 (1947), p. 11 (also quotation).

48 S. Nita, Powszechna oświata rolnicza, „Nowe Wyzwolenie” 27 (1946), p. 13.

49 An example: the, later, member of the parliament Władysław Ryncarz.
} 
sometimes accepted by PSL boards. It made it easier for these organizations to receive subsidies from authorities which were controlled by PPR. The leaderships of these organizations were dominated by PSL.

It is commonly known, that communists falsified the results of parliamentary elections of January 1947. Among the 11 MPs of „New Liberation” were the „Wici” activists. The majority of the MPs were teachers (Drzewiecki, Rękas, Wladyslaw Kosydarski). School visitor Władysław Kurkiewicz wrote books on history and political science for young readership (i.a. in a publishing house controlled by the Ministry of Education).

Among the others was the former county governor, a PSL member Stanisław Karpała, a passionate sculptor.

„New Liberation" deputies were present in almost all permanent committees of the parliament. For example, in the National Defense Commission and the Culture and Art Commission the party was represented by Witold Oleszczak. ${ }^{50}$

The party's chances to be active in parliament were, however, very small. In February and March 1947, PPR forced most „Liberators” to join the so called „Lublin” SL. The support of the Temporary Constitution by the Party in the parliament did not help. ${ }^{51}$ Party's head assured that the "New Liberation” continued to strive for a comprehensive equality of peasants, workers and white collars, including appropriate support for the education of peasant youth, but in vain. ${ }^{52}$ The activists and members of the Party were powerless in the face of PPR purge in education system in the country, after the parliamentary election and the rise of influence of the „Lublin” SL in educational organizations. They did not have any influence on the results of the elections in the structures of the Polish Teachers' Union. ${ }^{53}$ "Lublin" SL openly declared that country teachers should only join their ranks. While praising the government's policy in recent years, they quite openly acknowledged that some country children still did not have access to primary education..$^{54}$

${ }^{50}$ G. Bołcun, Wojsko i obronność w pracach Sejmu Ustawodawczego Rzeczpospolitej Polskiej w latach 1947-1952, Warszawa 2006, Neriton, p. 287.

51 T. Skrzyński, Miejsce..., pp. 49, 60-61, 80-82, 92-93, 100.

${ }^{52}$ IPN, BU 0/1355/141, Protocole of the meeting ZW PSL "New Liberation" from the province of Warsaw 2 III 1947, p. 576; T. Skrzyński, Wokót..., p. 16.

53 i.a. A. Włodarczyk, Oświata na Dolnym Śląsku w latach 1945-1948, Warszawa - Wrocław 1989, PWN, p. 115-116.

${ }^{54}$ S. Mauersberg, M. Walczak, Oświata polska 1944-1956. Wybór źródeł, cz. 1, Warszawa 1999, Polskie Towarzystwo Pedagogiczne, p. 500. 
In June 1947, Members of the „New Liberation”, together with the Polish Peasant Party, voted against the Act on the Supervision of Assessment and Collection of Land Tax. Although the result of the voting in the parliament was obvious - they had no choice. The Act was very unfavorable for peasants. The „Liberators” also knew the generally hostile sentiments towards PPR in the countryside. ${ }^{55}$

PPR enforced termination of the Party at the end of 1947.

The idea of „New Liberation” to partially represent the interests of the village in the parliament was unrealistic. The „Liberators” failed to notice the insincerity in PPR policy which tended to gradually eliminate any independence of the country, and then the autonomy of all peasant organizations, including the educational ones.

\section{Bibliography}

Archiwum Instytutu Pamięci Narodowej w Warszawie.

„Nowe Wyzwolenie” 1946.

„Sprawozdanie Stenograficzne z Posiedzeń Krajowej Rady Narodowej”, 11 (1946).

Mauersberg S., Walczak M., Oświata polska 1944-1956. Wybór źródeł, cz. 1, Warszawa 1999, Polskie Towarzystwo Pedagogiczne.

Dziubka K., Władza, administracja i samorzad w koncepcjach polskiego ruchu ludowego 1944-1949, Wrocław 1992, Wydawnictwo Uniwersytetu Wrocławskiego.

Krasuski J., Ruch ludowy wobec szkolnictwa i oświaty wiejskiej w Polsce w latach 1939-1949, Kielce 1993, Wyższa Szkoła Pedagogiczna.

Lewandowski Cz., Kierunki tak zwanej ofensywy ideologicznej w polskiej oświacie, nauce i szkołach wyższych w latach 1944-1948, Wrocław 1993, Wydawnictwo Uniwersytetu Wrocławskiego.

Romanek J., Powstanie i działalność Polskiego Stronnictwa Ludowego „Nowe Wyzwolenie” w województwie lubelskim, „Rocznik Historyczny Muzeum Historii Polskiego Ruchu Ludowego" 27 (2011), pp. 129-141.

Sejm Ustawodawczy Rzeczypospolitej Polskiej (1947-1952), ed. M. Rybicki, Wrocław Warszawa 1977, Ossolineum.

Skrzyński T., Kompromis czy kapitulacja. Poglądy PSL „Nowe Wyzwolenie”, PSL „Lewica” $i$ „odrodzonego" PSL na ustrój, rolę i zakres państwa w latach 1946-1949, in: Partie

55 T. Skrzyński, Miejsce..., pp. 54, 60-61, 89; B. Dereń, Polskie Stronnictwo Ludowe w Krakowskiem 1945-1947, Warszawa 1998, Muzeum Historii Polskiego Ruchu Ludowego, p. 199. 
i ruchy chłopskie i ludowe w Europie wobec problemów współczesności. Państwo - forma, rola i zadania, eds. J. Gmitruk, A. Indraszczyk, S. Stępka, Warszawa 2014, Muzeum Historii Polskiego Ruchu Ludowego i Wydział Nauk Społecznych SGGW, pp. 33-55.

Skrzyński T., Miejsce na scenie politycznej i losy PSL „Nowe Wyzwolenie”, PSL „Lewica” oraz „odrodzonego” PSL w latach 1946-1949 (1950), Warszawa 2015, Muzeum Historii Polskiego Ruchu Ludowego.

Skrzyński T., Reprezentacja PSL „Nowe Wyzwolenie”, PSL „Lewica” i „odrodzonego” PSL w Krajowej Radzie Narodowej i Sejmie Ustawodawczym „Rocznik Historyczny Muzeum Historii Polskiego Ruchu Ludowego” 32 (2016), pp. 55-80.

Szpytma M., Próby dezintegracji ruchu ludowego w Polsce południowej na przykładzie Małopolskiej Grupy „Jedność Ludowa” (1946-1947), in: Represje wobec wsi i ruchu ludowego 1944-1956. Materiały z konferencji naukowej, 1, ed. J. Gmitruk, Z. Nawrocki, Warszawa 2003, Muzeum Historii Polskiego Ruchu Ludowego, IPN, pp. 115-132.

Szuba L., Polityka oświatowa państwa polskiego w latach 1944-1956, Lublin 2002, Towarzystwo Naukowe KUL.

Turkowski R., Polskie Stronnictwo Ludowe w obronie demokracji 1945-1949, Warszawa 1992, Wydawnictwo Sejmowe. 